hiding-place. This indicates that he gets visual indications of small unconscious movements by one or more persons in the audience.

In another series of experiments, Marion exhibited a power superior to that of Cumberlandism or muscle-reading by finding hidden objects when followed by a single person who knew the hiding. place. Progressive covering up of this agent by a wooden box showed that Marion could still succeed even when he could see no more than the agent's feet. If the agent was totally covered and wheeled round the room, failure ensued. In this case slight changes in the movements of walking appear to be the principal indicia. This result clearly indicates that in any telepathic experiment the agent should not be visible to the percipient.
In Section 2, Marion's power of recognizing cards which he had previously handled, when mixed in a new pack, is studied, and it is shown that this is probably due to tactual discrimination of a high order. His departure abroad prevented experiments to see if he could emulate the blind osteopath, Captain Lowry, by distinguishing the pips on a playing-card by sense of touch alone.

Further statistical and other tests in telepathy and clairvoyance are described in Section 3 ; but no evidence was provided of any faculty for reading the contents of sealed envelopes or of divining numbers thought of by members of an audience. Marion's claims as regards graphology and psychometry also seem to be without foundation.

\title{
Transatlantic Steam Navigation a Century Ago
}

\section{Jusis} ST when the S.S. Sirius and the S.S. Great Western were being advertised to sail on their first passages to New York, and on the day, March 31, 1838, the Great Western left the Thames for the Severn, preparatory to starting on her voyage on April 8, the Athenceum published an article running to four pages under the title "Atlantic Steam Navigation". This was one of several articles in the same journal all of which were written with a good knowledge of the subject and in an unprejudiced manner. From the article which appeared in the issue of March 31, the following passages are taken :

"There is really no mistake then in this long talked of project of navigating the Atlantic Ocean by steam. There is no doubt, that is, of the existence of the intention to make the attempt, and to give the experiment, as such, a fair trial. Nor is the intention entertained (like many innovations sometimes more ingenious than will bear much examination) by an irresponsible party, or by one party alone, as we shall presently show. The whole commercial community, at least of our own country, and we may add of the United States, are alive to its interest. In Liverpool, New York and the 'Great Metropolis'-the three depots of the mercantile navigation of Christendom . . . the work goes bravely on. The Sirius is absolutely getting under weigh, while we write this paragraph, for America New York, via Cork! The buzz of excitement yesterday reached even the secluded walls of our own study. We rushed down to Blackwall pell-mell, in an omnibus, like all the rest to see not the Sirius but the Great Western, which the papers have told us so much about for a month past. . . . Groups of nobility and gentry, with his Grace of Wellington at their head, figured in the cabin album; and we met as we came back, the Lord Mayor with his state carriage and four footmen rolling in gold, dashing down to Blackwall to get a last glimpse; all in pursuit, in a word, of the great animals of the day-the steamers now starting for the other side of the Atlantic.

"There is no mistake, then, we repeat, as to the trial of the experiment."

The writer of the article then went on to deal with the Sirius, the Great Western, the companies, the construction of the British Queen at Limehouse, the charges to be made for passengers and letters, the attitude of the Liverpool shipowners and other matters. "Our space," he concluded, "is now small for discussing anew the policy or subsequent prospects of this scheme. We consider it, however, in that view, a subject of very considerable importance, as well as of the most curious and teeming interest. If sustained, there can be no doubt of its vast advantage in speed. . . . For the mails, for the immense and vastly increasing correspondence between the two countries, for all personal intercommunication of mercantile men ... this is a vital and conclusive point. We must count also on an increase in travel. ling, if not of trade. . . .

"We think the sum of it, for the present, may be taken thus:-the practicability of steam will be established at once. Its speed and its certainty will induce interests, enough for its maintenance, to a greater or lesser extent to support it. All correspondence will be conveyed by it; all mercantile travel and some goods. Most passengers may be shy of it for a time-many for a long time (as some are of railroads still); accidents will happen of course; still the scheme will go on to maturity. Of its influence on other and far greater interests than yet alluded to, we cannot now speak. This is a scheme not to be hastily treated. It is one, too, which may be deferred awhile. All eyes now are turned on the "commencement of the end". We may yet discuss with improved data, the end of such a beginning."

The Great Western, the first steam vessel designed for the Atlantic passage, it may be added, was $212 \mathrm{ft}$. between perpendiculars, $35 \mathrm{ft}$. wide inside the paddle boxes and on a draught of $16 \mathrm{ft}$. 8 in. displaced 2,300 tons. Built of wood, she was strengthened in an elaborate manner by diagonal trussing of wood and iron and was copper sheathed. She had four boilers designed to work at $5 \mathrm{lb}$. pressure and her engines developed about $\mathbf{7 5 0}$ horse-power. Her machinery weighed nearly 400 tons and she stowed about 600 tons of coal. She left Blackwall early on March 31, 1838, and when she was between Gravesend and Southend a fire broke out around the base of the funnel which threatened to spread to the ship. The fire, however, was got under and the ship eventually left the Severn on her maiden voyage on April 8. 